\title{
Effects of iodine intake and teat-dipping practices on milk iodine concentrations in dairy cows
}

\author{
S. I. Borucki Castro, ${ }^{*}$ R. Berthiaume, ${ }^{*}$ A. Robichaud, $†$ and P. Lacasse ${ }^{\star 1}$ \\ *Dairy and Swine Research and Development Centre, Agriculture and Agri-Food Canada, 2000 College St., Sherbrooke, QC, Canada J1M 0C8 \\ †Food Directorate, Health Products and Food Branch, Health Canada, 1001 St-Laurent St. W., Longueuil, QC, Canada J4K 1C7
}

\begin{abstract}
Two studies were conducted to determine the effects of dietary iodine and teat-dipping practices on iodine concentrations in milk. In the first study, 63 cows in mid lactation were assigned to a $3 \times 3$ factorial design in which the main effects were dietary iodine levels (0.3, 0.6, and $0.9 \mathrm{mg}$ of dietary $\mathrm{I} / \mathrm{kg}$ of dry matter) and 3 different postdip managements (chlorhexidine with dip cup, $1 \%$ iodine dip cup, and $1 \%$ iodine by manual spray). During the 13-d pre-experimental period and the 15-d experimental period, noniodized sanitizers were used in premilking management. During the pre-experimental period, the levels of milk iodine averaged $241.2 \pm 5.8 \mu \mathrm{g} / \mathrm{kg}$, and no relationship was found with lactation number, days in milk, or milk production. Milk iodine concentrations increased linearly with iodine intake. Although teat dipping with $1 \%$ iodine had no effect on milk iodine concentration, the same solution applied by spraying greatly increased milk iodine levels. The second study was conducted to determine the effects of udder preparation before milking on milk iodine concentrations. Thirty-two lactating cows were assigned to 4 treatments: no predip (Con); predip with a predip solution containing $0.5 \%$ iodine + complete cleaning (Comp); predip with a postdip solution containing $1 \%$ iodine + complete cleaning (Post); and predip with a predip solution containing $0.5 \%$ iodine + incomplete cleaning (Inc). During the 14-d pre-experimental period and the 19-d experimental period, cows were fed the same diet, and noniodized sanitizers were used for postmilking dipping. During the last week of treatment, milk iodine averaged 164, 189, 218, and $252 \pm 9.8 \mu \mathrm{g} / \mathrm{kg}$ for Con, Comp, Post, and Inc, respectively. Preplanned orthogonal contrasts indicated that predipping with a $0.5 \%$ iodine predip solution completely wiped off (Comp) tended to increase milk iodine content above that of the control and that the iodine content of Post and Inc were higher than
\end{abstract}

Received July 4, 2011.

Accepted September 6, 2011.

${ }^{1}$ Corresponding author: Pierre.Lacasse@agr.gc.ca that of the Comp treatment. The results of the first experiment confirm that, to preserve milk safety, iodine should not be fed above requirements. Spraying iodinebased teat-dipping solutions results in large increases in milk iodine content and should be avoided. Predipping teats with an iodine-based sanitizer is an acceptable practice, but must be performed with the appropriate product and completely wiped off before milking.

Key words: food safety, milk quality, iodophor, milking management

\section{INTRODUCTION}

Currently, iodine deficiency is uncommon in North America (IOM, 2001). Cow milk has become one of the most important sources of nutritional iodine in several countries (Fischer and Giroux, 1987; Dahl et al., 2003; Pearce et al., 2004). Because of the iodine in milk, part of the population may be consuming iodine in excess. Indeed, the tolerable iodine intake level could easily be exceeded with high milk iodine concentrations (Scientific Committee on Food, 2002). In 2004-2005, a study was conducted in Canada on 411 retail milk samples from 9 provinces and 34 brand names. The samples were collected and analyzed by Health Canada (A. Robichaud, unpublished results), which indicated that the average iodine content of Canadian retail milk was high $(393 \pm 150 \mu \mathrm{g} / \mathrm{kg})$.

Between 2007 and 2008, 500 dairy farms were sampled to study the levels of iodine in bulk-tank milk in all provinces of Canada (Borucki Castro et al., 2010a). A key finding of this study was that most of the iodine in milk that reaches the consumer is already present at the farm gate. Iodine levels in bulk-tank milk averaged $304 \pm 8.4 \mu \mathrm{g} / \mathrm{kg}$ but ranged from 54 to $1,902 \mu \mathrm{g} / \mathrm{kg}$. Teat-dipping practices showed associations with iodine levels in milk; however, the effect appeared to be modulated by the way in which the sanitizer was applied. In a subsequent study (Borucki Castro et al., 2010b), samples of different feeds and information about feeding management were collected from the farms with high $(554 \mu \mathrm{g} / \mathrm{kg})$ and low $(103 \mu \mathrm{g} / \mathrm{kg})$ milk iodine concentrations. Most farms were feeding cows diets with 
more than twice the recommended iodine concentration (0.5 mg of iodine/ $\mathrm{kg}$ of DM; NRC, 2001). Although a linear relationship was found between dietary iodine concentration and milk iodine, the relationship was weak, indicating that other factors do affect milk iodine concentration.

Although the survey results suggested that feeding and teat-dipping practices were the main determinants of milk iodine concentration, controlled studies are needed to confirm and quantify their respective contributions. Therefore, our objective was to determine the effects of different practices on milk iodine: (1) the effects of dietary iodine concentrations; (2) the effects of different forms of application of the iodized sanitizers in postmilking; and (3) the effects of appropriate and inappropriate use of iodized sanitizers in premilking.

\section{MATERIALS AND METHODS}

The experiments took place at the Dairy and Swine Research and Development Centre of Agriculture and Agri-Food Canada in Sherbrooke, Québec, Canada. Animal care was in accordance with the guidelines of the Canadian Council on Animal Care (1993) and the protocol was approved by the local Institutional Animal Care Committee.

\section{Experiment 1}

Sixty-three Holstein cows $157 \pm 49.2$ DIM and $634 \pm$ $60.1 \mathrm{~kg}$ of BW were included in the experiment. A $13-\mathrm{d}$ pre-experimental period, in which all cows were fed to requirements and no iodine sanitizer was used, was performed to eliminate the effects of previous iodine intake and iodophor usage. During the 19 experimental days that followed, cows were assigned to treatments according to a $3 \times 3$ factorial design. The main effects tested were (1) dietary iodine concentrations and (2) postmilking sanitizer management. Diets were formulated to provide (1) $0.25 \mathrm{mg} / \mathrm{kg}$ of DM (low), (2) $0.5 \mathrm{mg} / \mathrm{kg}$ of DM (recommended), or (3) $1 \mathrm{mg} / \mathrm{kg}$ of DM (high) levels of iodine. The analysis of the TMR indicated that the actual concentration of iodine fed differed slightly from the specified levels, averaging $0.3 \pm 0.04,0.6 \pm$ 0.04 and $0.9 \pm 0.23 \mathrm{mg} / \mathrm{kg} \mathrm{DM}$ for low, recommended, and high iodine diets, respectively. A basal diet was formulated to cover the requirements of a lactating cow weighing $600 \mathrm{~kg}$ and producing $35 \mathrm{~kg} / \mathrm{d}$ (Table 1). Mineral mixes were used to adjust the iodine concentrations (Table 2). The source of iodine in the mineral mixes was ethylenediamine dihydroiodide (EDDI). Diets were prepared once and distributed twice daily (1000 and $1600 \mathrm{~h}$ ). Cows were fed ad libitum in amounts designed to ensure a $10 \%$ feed refusal level and were maintained in tie stalls; however, they were milked in a milking parlor at 0800 and $2000 \mathrm{~h}$. Water was freely available to all cows. The postmilking management treatments were (1) teat dipping with a chlorhexidine-based sanitizer (Chlorex); 2) teat dipping with a 1\% iodine sanitizer (Dip); and 3) teat spraying with a $1 \%$ iodine sanitizer (Spray). The products used were Apprehend (0.52\% wt/wt chlorhexidine-acetate, Westfalia Surge, Naperville, IL) for the Chlorex treatment and Teat-Kote 10/ III ( $1 \%$ wt/wt nonyl-phenoxypoly-ethyleneoxy ethanol iodine complex with $9.3 \%$ wt/wt glycerin emollient, Westfalia Surge) for the Dip and Spray treatments. Prior to milking, the teats were cleaned with an udderwash cloth containing no iodine (Udderoclean, Ukal Canada, St-Hyacinthe, QC, Canada). During the preexperimental period, all animals were fed the diet with the recommended level of iodine, and chlorhexidine was used as the teat sanitizer in postmilking. The first 14 $\mathrm{d}$ of the treatment period were used as an adaptation period.

Dietary ingredients and water were sampled at the beginning of the experiment. Samples of TMR and milk were collected on $\mathrm{d}-13,-7,1,8,15,17$, and 19 relative to the start of the treatment period. The amount of feed offered and orts were recorded during the last 2 wk of the pre-experimental period and during the experimental period. Milk production was recorded daily. Milk fat and protein were analyzed based on samples taken on d 9 of the experimental period. Total iodine concentration was determined in the ingredients, TMR, and milk samples. Blood samples were collected from the tail vein with Vacutainer tubes (BD serum Vacutainers 367820; Becton Dickinson, Franklin Lakes, NJ) on $\mathrm{d}-13,1,8$, and 15 , and left at room temperature for $2 \mathrm{~h}$ to permit clotting. Serum was then collected after centrifugation at $5,000 \times g$ for $10 \mathrm{~min}$ at $4^{\circ} \mathrm{C}$ and frozen at $-20^{\circ} \mathrm{C}$ until analysis.

\section{Experiment 2}

Thirty-two lactating cows $119 \pm 87.9$ DIM and 674 $\pm 58.1 \mathrm{~kg}$ of BW were included in this experiment. A 2-wk pre-experimental period, in which no predipping was performed, was used to eliminate the effects of previous iodine intake and iodophor usage. During the 3 experimental weeks that followed, cows were assigned to 1 of the following 4 treatments: (1) no teat dipping before milking (udderwash without iodine; Con); (2) teat dipping before milking with a predipping sanitizer ( $0.5 \%$ iodine; Theratec Plus, Westfalia Surge) + complete cleaning with paper towels (Comp); (3) teat dipping before milking with a postdip sanitizer (1\% iodine, Teat Kote 10/III, Westfalia Surge) + complete cleaning with paper towels (Post); and (4) teat dipping before 
milking with a predip sanitizer (Theratec, Westfalia Surge) + incomplete cleaning with paper towels (Inc). Incomplete cleaning was performed by cleaning only 3 of the 4 teats. All cows received a balanced diet similar to the recommended iodine level diet in experiment 1 $(0.56 \pm 0.4 \mathrm{mg}$ of iodine $/ \mathrm{kg}$ of $\mathrm{DM})$. A chlorhexidinebased sanitizer (Apprehend, Westfalia Surge) was used for postdipping of all cows during the pre-experimental period and the experimental period. The first $2 \mathrm{wk}$ of treatment were considered an adaptation period.

Samples of milk were collected on d $-14,-7,1,8$, 15,17 , and 19 relative to the start of the experimental period. Feed intake was measured during the last week of the experimental period. Weekly feed samples were taken during the pre-experimental and experimental periods.

\section{Analytical Methods}

Iodine in feeds and milk was analyzed in the Longueuil (QC) Health Canada laboratory, which is accredited by the Standards Council of Canada. Total iodine concentration (organic and inorganic) was determined using the method of Benkhedda et al. (2009), which involves inductively coupled plasma mass spectrometry (7500 series model, Agilent Technologies, Santa Clara, CA) optimized for raw milk samples. Before analysis, the samples were digested in a closed microwave system with a mixture of perchloric and nitric acids. The detection limit was $12 \mathrm{ng} / \mathrm{g}$ for a 0.5 -g sample, with precision levels of $4.0 \%$ and $2.2 \%$ obtained for 10 replicate measurements of $50-$ and $1,000-\mathrm{ng} / \mathrm{g}$ standards.

The total thyroxine (T4) concentration was determined in serum by RIA using a commercial kit (Coata-Count, Siemens Healthcare Diagnostics Inc., Los Angeles, CA). Milk concentrations of fat, protein, and lactose, and SCC were determined by the Dairy Herd Analysis Service of Valacta (Ste. Anne de Bellevue, QC, Canada).

\section{Statistical Analyses}

The cows were blocked based on milk production, number of lactations, and DIM. The data were analyzed as repeated measurements using the MIXED procedure of SAS (Wang and Goonewardene, 2004; Littell et al., 2006). This analysis was performed for the experimental period as a whole (measures from d 1 to 19) and for the last week of measurements (d 15 to 19). The pretreatment levels were used as covariates. Preplanned orthogonal contrasts were used to calculate the linear and quadratic effects of dietary iodine in experiment 1 and to compare treatments in experiment 2. The Tukey adjusted test was used for other treatment compari-
Table 1. Ingredient and nutrient composition of the basal diet for experiments 1 and 2

\begin{tabular}{|c|c|}
\hline Item & Value \\
\hline \multicolumn{2}{|l|}{ Ingredient (\%) } \\
\hline Grass silage & 28.9 \\
\hline Corn silage & 28.6 \\
\hline Cracked corn grain & 21.0 \\
\hline Soybean meal, $48 \%$ & 10.2 \\
\hline Chopped grass hay & 5.5 \\
\hline Top supplement & 3.9 \\
\hline Vitamin and mineral premix & 1.5 \\
\hline Calcium carbonate & 0.4 \\
\hline \multicolumn{2}{|l|}{ Nutrient composition $^{1}$} \\
\hline $\mathrm{CP}(\%$ of $\mathrm{DM})$ & 16.4 \\
\hline $\mathrm{RDP}(\%$ of $\mathrm{CP})$ & 10 \\
\hline RUP (\% of $\mathrm{CP})$ & 37 \\
\hline Digestible RUP (\% of RUP) & 51.6 \\
\hline Digestible Lys ( $\%$ of $\mathrm{CP})$ & 6.05 \\
\hline Digestible Met (\% of CP) & 1.77 \\
\hline $\mathrm{NE}_{\mathrm{L}}(\mathrm{Mcal} / \mathrm{kg}$ of $\mathrm{DM})$ & 1.57 \\
\hline $\mathrm{NDF}(\%$ of DM) & 36.3 \\
\hline $\mathrm{ADF}(\%$ of $\mathrm{DM})$ & 24.0 \\
\hline $\mathrm{Ca}(\%$ of $\mathrm{DM})$ & 0.77 \\
\hline $\mathrm{P}(\%$ of $\mathrm{DM})$ & 0.40 \\
\hline $\mathrm{Mg}(\%$ of $\mathrm{DM})$ & 0.26 \\
\hline $\mathrm{K}(\%$ of $\mathrm{DM})$ & 1.53 \\
\hline $\mathrm{S}(\%$ of $\mathrm{DM})$ & 0.21 \\
\hline $\mathrm{Na}(\%$ of $\mathrm{DM})$ & 0.24 \\
\hline $\mathrm{Cl}(\%$ of $\mathrm{DM})$ & 0.47 \\
\hline $\mathrm{DCAB},{ }^{2} \mathrm{mEq} / \mathrm{kg}$ & 234 \\
\hline $\mathrm{Fe}(\mathrm{mg} / \mathrm{kg})$ & 209 \\
\hline $\mathrm{Zn}(\mathrm{mg} / \mathrm{kg})$ & 71 \\
\hline $\mathrm{Mn}(\mathrm{mg} / \mathrm{kg})$ & 63 \\
\hline $\mathrm{Cu}(\mathrm{mg} / \mathrm{kg})$ & 14 \\
\hline Co (mg/kg) & 0.9 \\
\hline $\mathrm{I}(\mathrm{mg} / \mathrm{kg})$ & 0.1 \\
\hline $\mathrm{S}(\mathrm{mg} / \mathrm{kg})$ & 0.3 \\
\hline Vitamin A (kIU/kg) & 6.73 \\
\hline Vitamin D (kIU/kg) & 0.86 \\
\hline Vitamin E (IU/kg) & 40 \\
\hline
\end{tabular}

${ }^{1}$ Agri-Gestion software from Valacta (Ste. Anne de Bellevue, QC, Canada).

${ }^{2} \mathrm{DCAB}=$ dietary cation-anion balance.

sons. Differences among treatments were determined to be significant if $P<0.05$. The model descriptions are as follows:

$$
\mathrm{Y}=\mu+\mathrm{B}+\mathrm{C}+\mathrm{D}+\mathrm{P}+\mathrm{DP}+\mathrm{e},
$$

where $\mathrm{Y}=$ dependent variable, $\mu=$ general mean, $\mathrm{B}$ $=$ block effect, $\mathrm{C}=$ pretreatment level (covariate), $\mathrm{D}$ $=$ feed level effect, $\mathrm{P}=$ postdip practice effect, $\mathrm{DP}=$ interaction between $\mathrm{D}$ and $\mathrm{P}$, and $\mathrm{e}=$ residual effect (experiment 1); and

$$
\mathrm{Y}=\mu+\mathrm{B}+\mathrm{C}+\mathrm{T}+\mathrm{e},
$$

where $\mathrm{Y}=$ dependent variable, $\mu=$ general mean, $\mathrm{B}$ $=$ block effect, $\mathrm{C}=$ iodine level pretreatment (covariate), $\mathrm{T}=$ predip practice effect, and $\mathrm{e}=$ residual effect (experiment 2). 
Table 2. Composition of the vitamin and mineral premix ${ }^{1}$ for the different dietary treatments of experiment 1

\begin{tabular}{lccc}
\hline & & Dietary treatment & \\
\cline { 2 - 4 } Ingredient & Low & Recommended & High \\
\hline $\mathrm{I}(\mathrm{mg} / \mathrm{kg})$ & 0.0 & 23.0 & 46.0 \\
$\mathrm{Ca}(\%$ of DM) & 9.41 & 9.13 & 8.92 \\
$\mathrm{P}(\%$ of DM) & 4.90 & 4.79 & 4.69 \\
$\mathrm{Mg}, \%$ of DM) & 4.90 & 4.79 & 4.68 \\
$\mathrm{~S}(\%$ of DM) & 1.54 & 1.52 & 1.50 \\
$\mathrm{Na}(\%$ of DM) & 14.0 & 13.72 & 1.45 \\
$\mathrm{~K}(\%$ of DM) & 1.39 & 1.37 & 1,968 \\
$\mathrm{Fe}(\mathrm{mg} / \mathrm{kg})$ & 2,059 & 2,013 & 1,043 \\
$\mathrm{Cu}(\mathrm{mg} / \mathrm{kg})$ & 1,093 & 1,068 & 1,754 \\
$\mathrm{Mn}(\mathrm{mg} / \mathrm{kg})$ & 1,839 & 2,656 & 2,595 \\
$\mathrm{Zn}(\mathrm{mg} / \mathrm{kg})$ & 2,718 & 57 & 56 \\
$\mathrm{Co}(\mathrm{mg} / \mathrm{kg})$ & 58 & 19.5 & 19.1 \\
$\mathrm{Se}(\mathrm{mg} / \mathrm{kg})$ & 20.0 & 265 & 259 \\
$\mathrm{~F}(\mathrm{mg} / \mathrm{kg})$ & 271 & 442,000 & 431,600 \\
Vitamin A (IU/kg) & 451,745 & 56,670 & 55,335 \\
Vitamin D (IU/kg) & 58,004 & 2,630 & 2,568 \\
Vitamin E (IU/kg) & 2,692 & & \\
\hline
\end{tabular}

${ }^{1}$ Belisle Solution Nutrition Inc. (Saint-Mathias, QC, Canada).

The association between milk iodine levels before the initiation of treatment in experiment 1 was examined using the SAS procedures CORR for continuous variables and REG for discrete variables (SAS Institute Inc., Cary, NC). Regression equations for milk iodine as a function of dietary iodine were calculated with the REG procedure of SAS.

\section{RESULTS AND DISCUSSION}

\section{Experiment 1}

Before the start of the treatments, the milk iodine concentration was similar among all groups of cows $(P$ $>0.6)$ and averaged $241.2 \pm 5.8 \mu \mathrm{g} / \mathrm{kg}$. Despite the fact that all cows were treated alike, milk iodine varied among animals $(\mathrm{SD}=46.2)$ and ranged from 151 to $341 \mu \mathrm{g} / \mathrm{kg}$. No relationships were found between milk production, DIM, DMI, milk composition (fat, protein, lactose, and SCC), BW, lactation number, or reproductive status and milk iodine. However, milk iodine levels before the onset of the experimental treatments and at the end of the experimental period were correlated $(\mathrm{r}=$ $0.4 ; P=0.001)$. This suggests that cows differ in their ability to transfer iodine into milk. The iodine concentration is higher in milk than in plasma (Swanson et al., 1990; Flachowsky et al., 2007) because the mammary gland contains transporters that actively transfer iodide from blood to milk. The level of these transporters can be modulated by lactogenic hormones (Rillema and Hill, 2003) and may constitute a control point. However, determination of the mechanism by which this divergence occurs would require further investigation.
No significant interaction $(P>0.1)$ was observed between dietary iodine and postmilking treatments on any of the variables and, therefore, results are presented according to main effects. A linear effect was found of dietary iodine content on milk iodine concentration $(P$ $<0.0001$; Figure 1). Along these lines, Miller et al. (1975) reported that the iodine concentration in milk increased in direct proportion to the amount of iodine fed, up to $162 \mathrm{mg}$ daily. Furthermore, dose-response relationships were found between the iodine concentrations in milk and dietary iodine fed as iodide, iodate, or organic iodine (Swanson et al., 1990; Franke et al., 2009).

In cows that received Chlorex as part of postmilking management and for which diet was the only significant source of iodine, milk iodine averaged $126 \pm 5,250 \pm$ 12 , and $375 \pm 15 \mu \mathrm{g} / \mathrm{kg}$ for low, recommended, and high iodine diets, respectively. Milk iodine concentration can be predicted by the following equation: milk iodine $(\mu \mathrm{g} / \mathrm{kg})=416 \times$ dietary iodine concentration $(\mathrm{mg} / \mathrm{kg}$ of $\mathrm{DM})+0.7\left(\mathrm{R}^{2}=0.8 ; P<0.001\right)$. The slope of this equation is steeper than that calculated by Franke et al. (2009); however, those authors used a much wider range of iodine supplementation (0 to $5 \mathrm{mg}$ of $\mathrm{I} / \mathrm{kg}$ of $\mathrm{DM}$ ) and had only one intermediary point (0.5) between 0 and $1 \mathrm{mg}$ of I/ $\mathrm{kg}$ of DM. Franke et al. (2009) also used different sources of iodine (potassium iodide and calcium iodate vs. EDDI), which have been shown to be less absorbable.

In the Chlorex cows, the carryover of dietary iodine into milk (calculated as $100 \times \mathrm{mg}$ of I milk/mg of intake I) was similar for each diet, averaging $47 \pm 1.8,49$ \pm 3.4 , and $51 \pm 2.5 \%$ for low, recommended, and high 


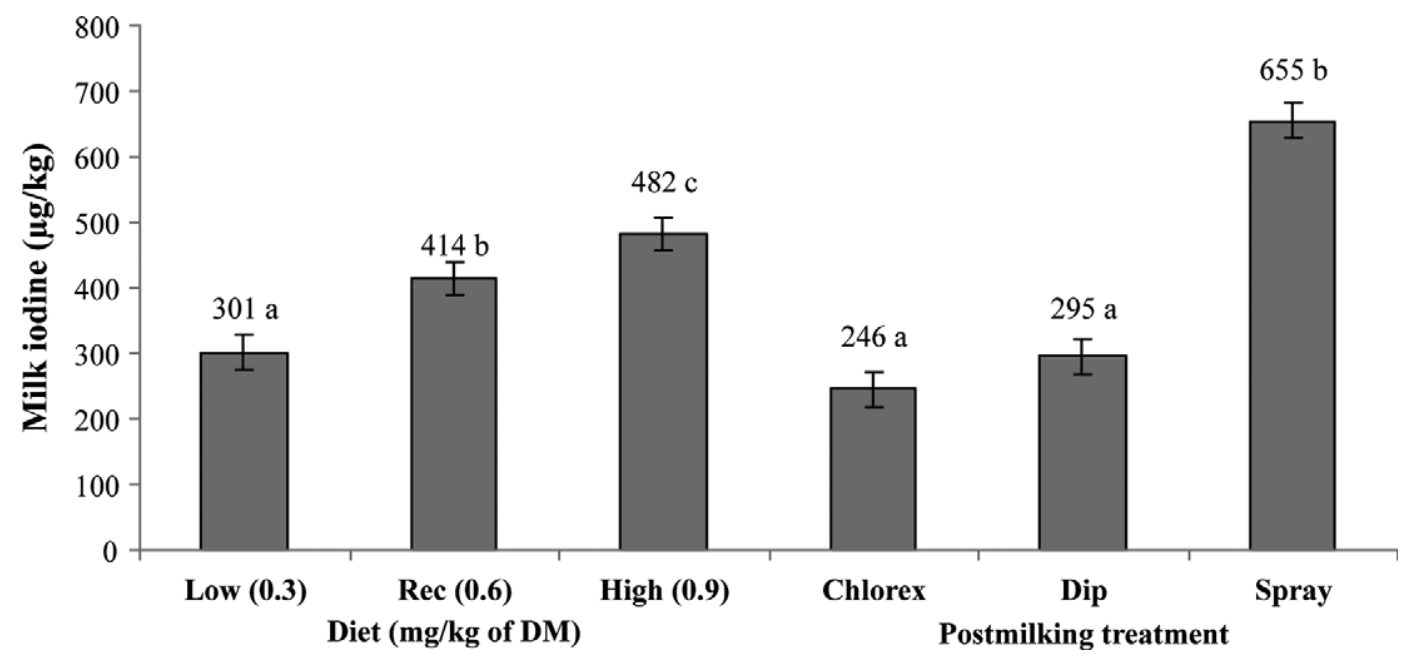

Figure 1. Experiment 1: Main effects of dietary iodine $[\mathrm{mg} / \mathrm{kg}$ of $\mathrm{DM}$; low, recommended (Rec), and high] and postmilking treatments $($ Chlorex $=$ chlorhexidine; Dip $=1 \%$ iodine dipping; Spray $=1 \%$ iodine spraying $)$ on milk iodine concentrations. Data are presented as LSM \pm SEM. Within the main effects, treatments with different letters differ $(P<0.05)$.

iodine diets, respectively. Swanson et al. (1990) and Schöne et al. (2009) reported carryover ranging from 30 to $40 \%$. Franke et al. (2009) reported carryovers levels of around $47 \%$ across a wide range of iodine supplementation levels ( 0 to $5 \mathrm{mg} / \mathrm{kg}$ of DM), but the carryover was reduced below $20 \%$ when a goitrogenic feed (rapeseed meal) was fed. Swanson et al. (1990) found great variability between cows, and some of the higher yielding cows had carryover of up to $60 \%$. Similarly, Moschini et al. (2010) reported that carryover increases with milk yield. We found that carryover varies with milk production $(P<0.0001)$; however, the low $\mathrm{R}^{2}$ value $(0.23)$ indicates that other factors are influencing the carryover of iodine into milk.

The iodine concentration in milk was not affected by dipping teats in $1 \%$ iodine sanitizer after milking (Figure 1). In other studies, the effect of postmilking iodine teat dipping ranged from no effect (Berg and Padgitt, 1985) to an increase of $184 \mu \mathrm{g} / \mathrm{L}$ (Iwarsson and Ekman, 1973). Postdipping with 0.3\% (Flachowsky et al., 2007) and $0.5 \%$ (Galton, 2004) iodine increased milk iodine between 33 and $54 \mu \mathrm{g} / \mathrm{kg}$, which is in the same range as the numerical difference between the Chlorex and Dip treatments. We believe that an increase of this magnitude would be acceptable, taking into account the benefits of lowering intramammary infection prevalence and SCC on milk quality.

Spraying with $1 \%$ iodine sanitizer at postmilking resulted in greater $(P<0.001$; Figure 1$)$ milk iodine concentrations than with Chlorex $(+409 \mu \mathrm{g} / \mathrm{kg})$ or Dip $(+360 \mu \mathrm{g} / \mathrm{kg})$. This is in agreement with the results of a national survey, in which it was observed that manual teat spraying resulted in similar milk iodine increases compared with teat dipping (Borucki Castro et al., 2010a). Conrad and Hemken (1978) reported that teat dipping of only the right udder half with an iodinebased sanitizer resulted in similar iodine increases in both left and right udder halves. Furthermore, milk iodine was markedly increased over the control group when iodine was applied to the skin between the vulva and the point of udder attachment in cows. Therefore, the primary mode by which postmilking teat dipping affects milk iodine concentration is absorption from the teat's surface and secretion into milk rather than contamination from the skin's surface. Spraying requires about $50 \%$ more disinfectant than dipping to achieve the same degree of teat cover (Blowey and Edmondson, 1996). In addition, a larger skin area is covered with the sanitizer when the teats are sprayed rather than dipped (Figure 2), increasing the absorption area. Finally, the skin of the teat is washed at each milking, whereas the skin of the mammary gland is not routinely washed, leaving more time for residues to be absorbed. These factors probably explain why spraying $1 \%$ iodine postdip dramatically increased the iodine in milk. These results suggest that automatic teat disinfection systems, which use more disinfectant and cover a larger skin area, would increase the milk iodine level even further. This is what we found in our national survey (Borucki Castro et al., 2010a); however, experimental verification has yet to be undertaken.

Dry matter intake, milk production, and milk composition were not affected by diet or postmilking treatments (Table 3). No significant effects of dietary iodine on DMI were found by Moschini et al. (2010). Neither milk fat nor milk protein components were affected in 

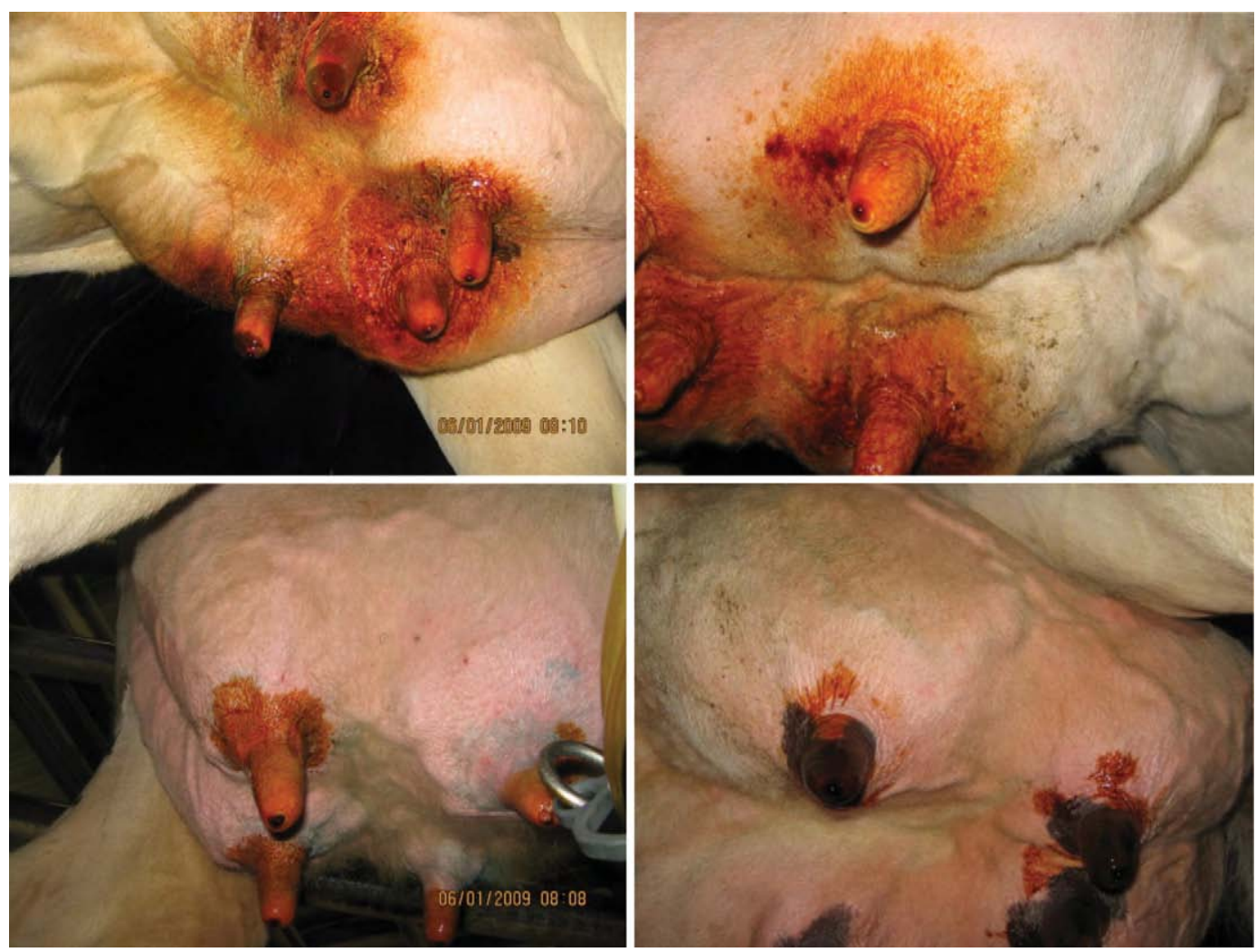

Figure 2. Experiment 1: Mammary gland after spraying (upper panel) or dipping (lower panel) with a 1\% iodine postdip sanitizer. Color version available in the online $\mathrm{PDF}$.

other studies in which dietary iodine ranged from 0.1 to $7.6 \mathrm{mg} / \mathrm{kg}$ of DM (Kaufmann et al., 1998; Norouzian et al., 2009). Thyroxine levels were not affected by the treatments (Table 4). Swanson et al. (1990) and Kaufmann et al. (1998) measured T4 concentrations similar to those reported here and they were unaffected by dietary iodine intake. Very high $(>3.4 \mathrm{mg} /$ $\mathrm{kg}$ of DM) iodine supplementation of lactating dairy cows did not affect T4 concentrations in other studies (Swanson, 1972; Convey et al., 1978). Reductions of plasma T4 concentration were reported after several months of feeding cows a very low iodine diet (0.06 $\mathrm{mg} / \mathrm{kg}$ of DM) and were associated with milk iodine concentrations below $50 \mu \mathrm{g} / \mathrm{kg}$ (Swanson, 1972). None of the cows in this study had milk iodine levels below the concentration $(25 \mu \mathrm{g} / \mathrm{kg})$ considered indicative of iodine deficiency (Alderman and Stranks, 1967).

\section{Experiment 2}

The results of the second experiment showed that milk iodine was significantly increased $(P<0.0001)$ by the use of iodized sanitizers in premilking (Figure 3). Predipping with $0.5 \%$ iodine predip solution followed

Table 3. Experiment 1: Effect of dietary iodine concentration and postmilking treatments on feed intake, milk production, and milk composition ${ }^{1}$

\begin{tabular}{|c|c|c|c|c|c|c|c|c|c|c|}
\hline \multirow[b]{2}{*}{ Item } & \multicolumn{3}{|c|}{ Effect of dietary iodine $(\mathrm{mg} / \mathrm{kg} ; \mathrm{I})$} & \multicolumn{3}{|c|}{ Effect of postmilking treatment (T) } & \multirow[b]{2}{*}{ SEM } & \multicolumn{3}{|c|}{ Effect $P<$} \\
\hline & $\begin{array}{l}\text { Low } \\
(0.3)\end{array}$ & $\begin{array}{c}\text { Recommended } \\
(0.6)\end{array}$ & $\begin{array}{l}\text { High } \\
(0.9)\end{array}$ & $\begin{array}{l}\text { Chlorhexidine } \\
\text { dip }\end{array}$ & $\begin{array}{c}\text { Iodine } \\
\text { dipping } 1 \%\end{array}$ & $\begin{array}{c}\text { Iodine } \\
\text { spraying } 1 \%\end{array}$ & & I & $\mathrm{T}$ & $\mathrm{I} \times \mathrm{T}$ \\
\hline DMI $(\mathrm{kg})$ & 23.1 & 22.0 & 22.8 & 23.2 & 22.6 & 22.0 & 0.93 & 0.35 & 0.34 & 0.62 \\
\hline Milk production $(\mathrm{kg} / \mathrm{d})$ & 26.8 & 26.7 & 27.8 & 27.4 & 27.3 & 26.5 & 1.84 & 0.42 & 0.54 & 0.92 \\
\hline Milk protein (\%) & 3.34 & 3.40 & 3.37 & 3.30 & 3.40 & 3.40 & 0.047 & 0.66 & 0.23 & 0.99 \\
\hline Milk protein $(\mathrm{kg})$ & 0.91 & 0.95 & 0.94 & 0.93 & 0.93 & 0.93 & 0.021 & 0.26 & 0.98 & 0.50 \\
\hline Milk fat $(\%)$ & 3.71 & 3.73 & 3.74 & 3.60 & 3.79 & 3.80 & 0.106 & 0.98 & 0.31 & 0.76 \\
\hline Milk fat (kg) & 1.00 & 1.03 & 1.04 & 1.01 & 1.04 & 1.02 & 0.028 & 0.55 & 0.79 & 0.63 \\
\hline $\mathrm{SCC}(\times 1,000$ cells $/ \mathrm{mL})$ & 115 & 108 & 123 & 119 & 99 & 127 & 36.3 & 0.96 & 0.84 & 0.53 \\
\hline
\end{tabular}

${ }^{1}$ Data are presented as LSM of the last week of the experiment. 
Table 4. Experiment 1: Effect of dietary iodine concentration and postmilking treatments on plasma thyroxine concentration of lactating cows ${ }^{1}$

\begin{tabular}{|c|c|c|c|c|c|c|c|c|c|c|}
\hline \multirow[b]{2}{*}{$\begin{array}{l}\text { Thyroxine, } \\
(\mu \mathrm{g} / \mathrm{dL})\end{array}$} & \multicolumn{3}{|c|}{ Effect of dietary iodine $(\mathrm{mg} / \mathrm{kg} ; \mathrm{I})$} & \multicolumn{3}{|c|}{ Effect of postmilking treatment $(\mathrm{T})$} & \multirow[b]{2}{*}{ SEM } & \multicolumn{3}{|c|}{ Effect $P<$} \\
\hline & $\begin{array}{l}\text { Low } \\
(0.3)\end{array}$ & $\begin{array}{c}\text { Recommended } \\
(0.6)\end{array}$ & $\begin{array}{l}\text { High } \\
(0.9)\end{array}$ & $\begin{array}{l}\text { Chlorhexidine } \\
\text { dip }\end{array}$ & $\begin{array}{c}\text { Iodine } \\
\text { dipping 1\% }\end{array}$ & $\begin{array}{c}\text { Iodine } \\
\text { spraying } 1 \%\end{array}$ & & I & $\mathrm{T}$ & $\mathrm{I} \times \mathrm{T}$ \\
\hline Day 1 & 4.45 & 4.33 & 4.09 & 4.25 & 4.33 & 4.30 & 0.219 & 0.44 & 0.95 & 0.68 \\
\hline Day 19 & 4.78 & 4.67 & 4.47 & 4.63 & 4.66 & 4.66 & 0.256 & 0.55 & 0.99 & 0.96 \\
\hline
\end{tabular}

${ }^{1}$ Data are presented as LSM.

by complete drying of the teat (Comp) tended $(P=$ 0.08 ) to increase milk iodine content above that of the Con treatment. Galton et al. (1984) and Rasmussen et al. (1991) reported that predipping with $0.5 \%$ iodine predip solutions followed by complete drying of the teat did not significantly increase milk iodine content.

The use of a $1 \%$ iodine postmilking sanitizer (Post) increased milk iodine above that obtained with the Comp treatment $(P<0.05$, Figure 3). Galton et al. (1984) observed that predipping with $1 \%$ iodine postdip solution increased milk iodine content. The higher iodine content of the postdip solution probably plays a role, given that Galton et al. (1986) reported an increase in milk iodine with a $1 \%$ iodine sanitizer but not with $0.1 \%$ sanitizer. However, Rasmussen et al. (1991) observed greater milk iodine concentrations with a $0.25 \%$ iodine teat dip than with a $0.5 \%$ iodine teat dip. These authors attributed this surprising result to the fact that the $0.5 \%$ teat dip was easier to remove, leaving less residue on the teat skin. Postdipping sanitizers contain more emollient than sanitizers designed for predipping, making them more viscous. This may have contributed to the greater iodine content in the Post treatment.

The Inc treatment (drying 3 teats instead of 4) significantly increased milk iodine concentrations above those of the Comp treatment $(P<0.001)$. Galton et al. (1984) reported that installing the milking unit without drying the teats after dipping in $1 \%$ iodine sanitizer increased milk iodine by $600 \mu \mathrm{g} / \mathrm{kg}$ above the level observed when teats were dried before milking. These results are consistent with our working hypothesis that the predipping effect on milk iodine is due to direct contamination of milk and is proportional to the amount of iodine present on the teat skin at the time the milking unit is installed.

\section{CONCLUSIONS}

Although no formal recommendation is given for the maximum allowable iodine content of milk, it would be reasonable to maintain the milk iodine concentra-

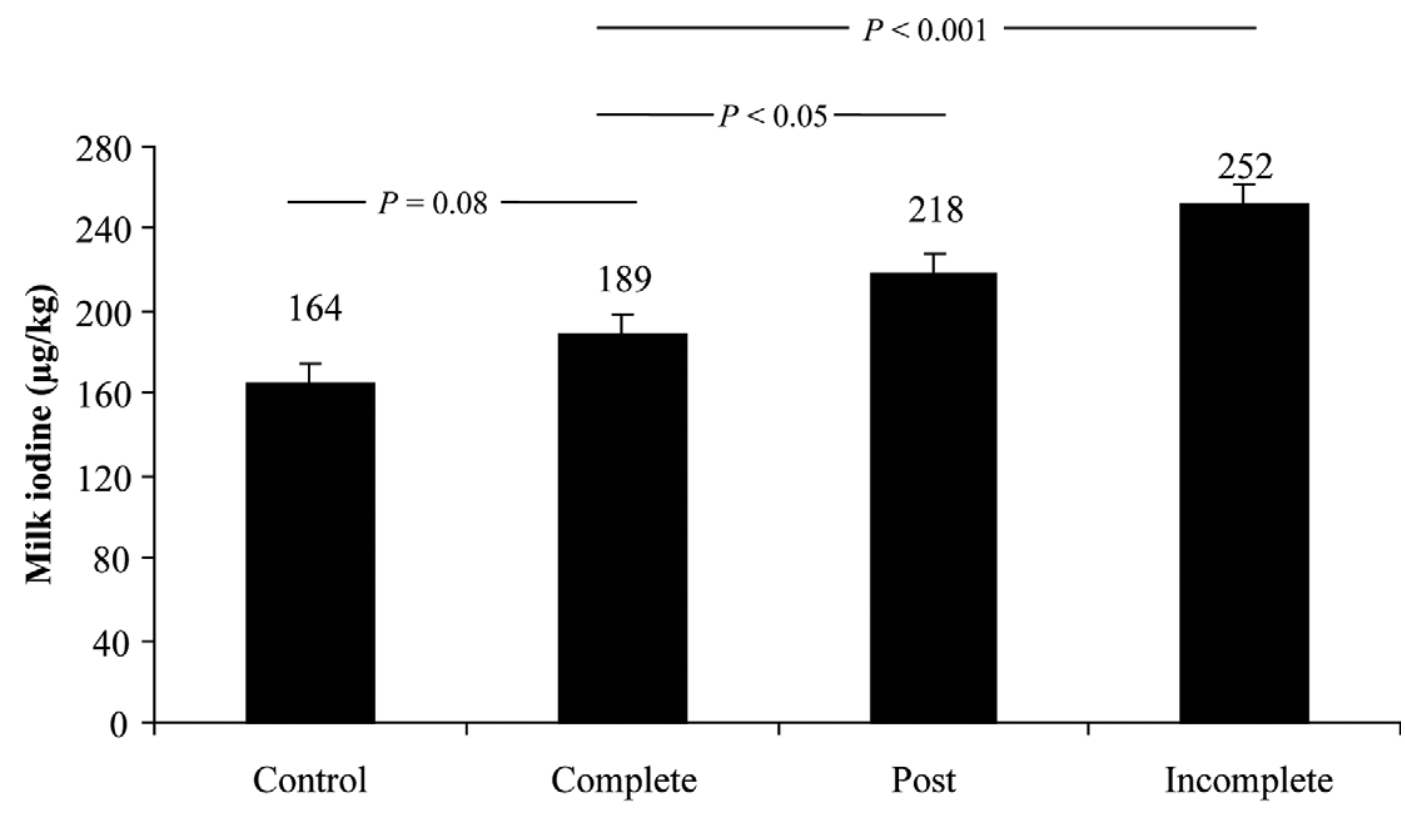

Premilking dipping treatments

Figure 3. Experiment 2: Milk iodine of lactating cows that were not predipped (Control), predipped with $0.5 \%$ predipping sanitizer that was completely dry before milking (Complete), predipped with a $1 \%$ iodine postdip sanitizer that was completely dry before milking (Post), or predipped with $0.5 \%$ predipping sanitizer that was not completely dry before milking (Incomplete). Data are presented as LSM \pm SEM. 
tion $<400 \mu \mathrm{g} / \mathrm{kg}$. At this concentration, a 3-yr-old child would have to consume more than $0.5 \mathrm{~L} / \mathrm{d}$ of milk to exceed the upper tolerable intake of iodine (IOM, 2001). Based on our results, to maintain the milk iodine concentration below this level, it is necessary to provide a diet with less than $1 \mathrm{mg} / \mathrm{kg}$ DM of iodine and, ideally, an amount near the NRC (2001) recommended level of $0.5 \mathrm{mg} / \mathrm{kg}$ of DM. Postmilking teat disinfection with an iodophor sanitizer is an acceptable practice when performed by dipping. However, if the sanitizer is applied by spraying, it is preferable to use an iodine-free sanitizer. Predipping with $0.5 \%$ iodine sanitizer has only a minor effect on iodine in milk. However, it must be performed using the appropriate product and the teats need to be completely cleaned before the milking unit is installed.

\section{REFERENCES}

Alderman, G., and M. H. Stranks. 1967. The iodine content of bulk herd milk in summer in relation to estimated dietary iodine intake of cows. J. Sci. Food Agric. 18:151-153.

Benkhedda, K., A. Robichaud, S. Turcotte, F. J. Beraldin, and K. A. Cockell. 2009. Determination of total iodine in food samples using inductively coupled plasma-mass spectrometry. J. AOAC Int. 92:1720-1727.

Berg, J. N., and D. Padgitt. 1985. Iodine concentrations in milk from iodophor teat dips. J. Dairy Sci. 68:457-461.

Blowey, R., and P. Edmondson. 1996. Teat disinfection in dairy herds. In Pract. 18:254-260.

Borucki Castro, S. I., R. Berthiaume, P. Laffey, A. Fouquet, F. Beraldin, A. Robichaud, and P. Lacasse. 2010a. Iodine concentration in milk sampled from Canadian farms. J. Food Prot. 73:1658-1663.

Borucki Castro, S. I., P. Lacasse, A. Fouquet, F. Beraldin, A. Robichaud, and R. Berthiaume. 2010b. Iodine concentrations in feeds in farms with contrasting levels of iodine in milk. J. Dairy Sci. 93(E Suppl. 1):45. (Abstr.)

Canadian Council on Animal Care. 1993. Guidelines to the Care and Use of Experimental Animals. 2nd ed. E. D. Olfert, B. M. Cross, and A. A. McWilliam, ed. Vol. I. CCAC, Ottawa, Ontario, Canada.

Conrad, L. M., and R. Hemken. 1978. Milk iodine as influenced by an iodophor teat dip. J. Dairy Sci. 61:776-780.

Convey, E. M., L. Chapin, J. Thomas, K. Leung, and E. Swanson. 1978. Serum thyrotropin, thyroxine, and tri-iodothyronine in dairy cows fed varying amounts of iodine. J. Dairy Sci. 61:771-775.

Dahl, L., J. A. Opsahl, H. M. Meltzer, and K. Julshamn. 2003. Iodine concentration in Norwegian milk and dairy products. Br. J. Nutr. 90:679-685.

Fischer, P. W. F., and A. Giroux. 1987. Iodine content of a representative Canadian diet. J. Can. Diet. Assoc. 48:24-27.

Flachowsky, G., F. Schone, M. Leiterer, D. Bemmann, M. Spolders, and P. Lebzien. 2007. Influence of an iodine depletion period and teat dipping in the iodine concentration of serum and milk of cows. J. Anim. Feed Sci. 16:18-25.

Franke, K., U. Meyer, H. Wagner, and G. Flachowsky. 2009. Influence of various iodine supplementation levels and two different iodine species on the iodine content of the milk of cows fed rapeseed meal or distillers dried grains with solubles as the protein source. J. Dairy Sci. 92:4514-4523.

Galton, D. M. 2004. Effects of an automatic postmilking teat dipping system on new intramammary infections and iodine in milk. J. Dairy Sci. 87:225-231.

Galton, D. M., L. Petersson, and H. Erb. 1986. Milk iodine residues in herds practicing iodophor premilking teat disinfection. J. Dairy Sci. $69: 267-271$.

Galton, D. M., L. Petersson, W. Merrill, D. Bandler, and D. Shuster. 1984. Effects of premilking udder preparation on bacterial population, sediment, and iodine residue in milk. J. Dairy Sci. 67:2580-2589.

IOM (Institute of Medicine). 2001. Iodine. Pages 258-289 in Dietary Reference Intakes. Report of the Panel on Micronutrients. Food and Nutrition Board. Natl. Academy Press. IOM, Washington, $\mathrm{DC}$

Iwarsson, K., and L. Ekman. 1973. The effect of a post-milking teat dip on the iodine concentration of bulk herd milk. Acta Vet. Scand. 14:338-340.

Kaufmann, S., A. Rambeck, J. Kursa, and V. Kroupova. 1998. Iodine in milk by supplementing feed: An additional strategy to erase iodine deficiency. Vet. Med. Czech 43:173-178.

Littell, R. C., G. A. Milliken, W. W. Stroup, R. D. Wollfinger, and O. Schabenberger. 2006. SAS System for Mixed Models. 2nd ed. SAS Institute Inc., Cary, NC.

Miller, J. K., E. Swanson, and G. Spalding. 1975. Iodine absorption, excretion, recycling, and tissue distribution in the dairy cow. J. Dairy Sci. 58:1578-1593

Moschini, M., M. Battaglia, G. Beone, G. Piva, and F. Masoero. 2010 Iodine and selenium carry over in milk and cheese in dairy cows: Effect of diet supplementation and milk yield. Animal 4:147-155.

Norouzian, M. A., F. Azizi, F. Shahroodi, M. Hedayati, M. Norouzian, and R. Valizadeh. 2009. The effect of feeding different levels of potassium iodide on performance, T3 and T4 concentrations and iodine excretion in Holstein dairy cows. J. Anim. Vet. Adv. 8:111-114

NRC. 2001. Nutrient Requirements of Dairy Cattle. 7th rev. ed. Natl. Academy Press, Washington, DC

Pearce, E. N., S. Pino, X. He, H. R. Bazrafshan, S. L. Lee, and L. E. Braverman. 2004. Sources of dietary iodine: Bread, cows' milk, and infant formula in the Boston area. J. Clin. Endocrinol. Metab. 89:3421-3424

Rasmussen, M. D., D. M. Galton, and L. G. Peterson. 1991. Effects of premilking teat preparation on spores of anaerobes, bacteria, and iodine residues in milk. J. Dairy Sci. 74:2472-2478.

Rillema, J. A., and M. A. Hill. 2003. Prolactin regulation of the pendrin-iodide transporter in the mammary gland. Am. J. Physiol. Endocrinol. Metab. 284:E25-E28.

Schöne, F., M. Leiterer, P. Lebzien, D. Bemmann, M. Spolders, and G. Flachowsky. 2009. Iodine concentration of milk in a dose-response study with dairy cows and implications for consumer iodine intake. J. Trace Elem. Med. Biol. 23:84-92.

Scientific Committee on Food. 2002. Opinion of the Scientific Committee on Food on the tolerable upper intake level of iodine. Accessed April 2011. http://ec.europa.eu/food/fs/sc/scf/out146_en.pdf.

Swanson, E. W. 1972. Effect of dietary iodine on thyroxine secretion rate of lactating cows. J. Dairy Sci. 55:1763-1767.

Swanson, E. W., J. Miller, F. Mueller, C. Patton, J. Bacon, and N. Ramsey. 1990. Iodine in milk and meat of dairy cows fed different amounts of potassium iodide or ethylenediamine dihydroiodide. J. Dairy Sci. 73:398-405.

Wang, Z., and L. A. Goonewardene. 2004. The use of MIXED models in the analysis of animal experiments with repeated measures data. Can. J. Anim. Sci. 84:1-11. 